\section{O MÉTODO DEMING DE ADMINISTRAÇÃO: W.EDWARDS DEMING, O GÊNIO AMERICANO QUE REVITALIZOU A INDÚSTRIA JAPONESA}

\section{MARY WALTON}

Rio de Janeiro, Marques Saraiva, 1989, $X X+276$ páginas.

\section{Por Alberto I. Sugo}

Doutorando em Administração pela EAESP/ FGV e professor de Teoria das Organizações no Departamento de Administraçāo Geral e Recursos Humanos da EAESP/FGV.

Depois da afluência da economia japonesa, a busca do segredo do sucesso japonês deparou inicialmente com as técnicas japonesas de administração, para depois descobrir que aquelas foram desenvolvidas a partir dos ensinamentos de dois americanos especialistas em qualidade: Juran e Deming, dois consultores tardiamente reconhecidos e seguidos em seu próprio país.

Deming tem agora a chance de ser escutado em sua terra, graças ao sucesso de seus disclpulos japoneses. O texto de Mary Walton, uma jornalista, tem o mérito de apresentar as idéias de Deming da mesma maneira pela qual o Método Deming tem sido difundido, isto é, sob a forma de seminários e de experiências concretas nas empresas, embora näo se descuide da localização histórica do movimento Deming de qualidade. Walton parece reproduzir fielmente o clima messiânico e de reverência que cerca Deming, o que nos permite uma melhor compreensão da proposta de Deming.

Feito a partir de entrevistas com Deming, com dirigentes de empresas que seguem a filosofia de qualidade de Deming écom material escrito sobre o método, o texto de Walton, apesar de estar organizado em a)notas bibliográficas, b)explanação dos princípios do método e clexemplos práticos da aplicaçăo do método, evita corretamente sistematizar o proprio método, o que poderia adulterar o espírito das idéias de Deming.

Deming prega a criação de qualidade, o que, levado a sério, implica em uma série de características da administração japonesa, como o trabalho em equipe, objetivos de longo prazo, relacionamento de compromisso com o fornecedor etc. A experiência profissional de Deming, que trabalhou na fábrica de Hawthorm ne à epoca de Elton Mayo, levou-o a observar que a busca da qualidade estaria condenada ao fracasso se tentada isoladamente, fora do contexto de um sistema administrativo. Os casos americanos descritos no livro mostram a extensẫo do método Deming: desde a transformaçäo do relacionamento chefe-subordinado em compromissos de cooperação, passando pela estreita interação da empresa com fornecedores e clientes, até a mudança na cultura e na filosofia da organização integrando todos os setores da empresa na busca da qualidade.

Assim como no caso de outras propostas feitas a partir de experiências práticas - como o Vencento a crise de Peters \& Waterman - o leitor desavisado poderá, ao folhear o livro, acreditar serem apenas superficiais e de senso comum os 14 pontos de Deming, pela falta de uma explicitaçăo de sua base teórica; mas o quadro mudará quando se enxergar no livro uma filosofia empresarial, exigindo reflexão sobre suas implicaçôes, que se tornam mais claras com o exame dos casos ilustrativos de aplicação do método Deming.

Materializando várias aspirações do Movimento de Relações Humanas, o Método Deming deve ser entendido como um movimento de administração, o que pode ser ilustrado com a premiação Deming no Japão ou com a afirmação do próprio Deming de que 
seu método só pode ter chances de sucesso se for difundido a todos, desde o topo até a base operária da empresa, incluindo fornecedores e concorrentes edientes de uma forma indireta.

A pergunta que fica é: até quando a administraçăo continuará a ser feita por movimentos e a ser envolvida pela aura do tecnicismo e do heroísmo?

\section{INOVAÇÃO, A VANTAGEM DE ATACANTE}

\section{RICHARD FOSTER}

Tradução do original, Innovation - The attacker's

Advantage, de José E. A. do Prado. Săo Paulo,

Best Seller, 1988, 292 páginas.

\section{Por Kurt Ernst Weil}

Professor no Departamento de Administraçăo de Produção e Operaçōes industriais da EAESP/FGV.

O livro de Foster é uma clara e interessante exposição do retorno obtido em investimentos em P\&D (Pesquisa e Desenvolvimento) e da estratégia associada para o defensor e para $o$ atacante com nova tecnologia.

A moral principal e: "Investir em tecnologias que estão virtualmente em seus limites faz tâo pouco sentido como investir em tecnologias que têtm muito potencial técnico mas pouco valor para o cliente" (pág. 170).

A técnica que procura ensinar é insistentemente repetida: reconhecer um atacante emergente, evitar insistir no velho, procurar entrar no novo campo por meio de licença, royalties etc. Infelizmente, o que o livro năo consegue mostrar é como reconhecer um desafiante que terá sucesso; uns falham, outros têm sucesso, portanto pânico não adianta.

Um ponto positivo do livro, muito de meu agrado, é a série de exemplos. Talvez o livro peque por falta de um perfil do empresário péssimo e do bom defensor (diretor, presidente etc.), perfil este muitas vezes salientado em revistas (Business Week, Fortune) ou estudos de casos na Harvard Business School. Mas nesse ponto basta ler os "agradecimentos" para notar que se trata de um trabalho coletivo, bem feito, onde a parte "tecnologia" talvez tenha sobrepujado o "perfil psicológico". Na página 17, es" tá escrito que "as pessoas décem mudar para gue? uma companhia adote uma nova tecnologia" (Robert Waterman Jr.). A experiência do resenhista na prática tem demonstrado que, mesmo mudando as pessoas, o medo é o desmotivador da mudança: medo de perder o emprego por fazer algo revolucionário. É mais provável alguém no escalão inferior criar nova tecnologia, mas a manter para si, sabendo que nunca seria aprovada pelo review board e seu ranking. Veja-se ofilme clássico inglếs "The man in the white suit", com Alec Guimess no papel título, inesquecivel como inventor do terno em tecido indestrutivel, que precisava ser cortado com maçarico, de tão resistente.

E após essas observaçŏes gerais sobre o livro, trago o meu protesto, como leitor, outra vez: o original tem índice remissivo e a tradução nacional não. Talvez seja possível explicar tudo isso pela diferença de preço. $O$ original custa US $\$ 19,95$ e a tradução nacional, em brochura, e tamanho de letra e margem menor, custava o equivalente a cerca de US\$ 12,00 no câmbio oficial e US\$ 6,50 no black, em março de 1989. Mesmo assim, o técnico norte-americano com seu MBA, mesmo de escola fora da listagem das melhores, ganha no mínimo US\$ 6.000 a 10.000 por mês e paga menos imposto de renda que o nosso gerente de produção a US\$ $1.600,00 /$ mess (no black), ou o professor titular da EAESP/FGV com seus US\$ 1.200,00 (no black). Some-se a isso que o norte-americano pode subtrair livros em sua declaraçăo, algo que a reforma do IR brasileiro suprimiu: portanto, porcentualmente, o norte-americano tem de pagar menos pelo livro.

O sumário do livro é o seguinte:

1. Por que Líderes Pexdem suas Posições

2. A Era da Descontinuidade

3. Compreendendo os Limites

4. A Curva-S: Um Novo Instrumento de Previsão

5. Como as Líderes de Mercado Tornam-se Perdedoras

6. O Dilema do Defensor

7. A Vantagem do Atacante

8. Contra-A taque: A Melhor Defesa

9. Fênix: Líderes que Permanecem Líderes

10. Metamorfose Orientadora

Epilogo: Além dos Limites

Apêndice I: Você Está Fazendo o Elementar?

Apêndice II: Avaliando a Ameaça (Traçando uma Curva-S)

Apêndice III: Escolhendo o Momento do Ataque (A Análise do Rendimento).

A técrica de como atacar ou saber se defender é ensimada nos três apêndices. É um método baseado em perguntas, e as respostas têm, evi" dentemente, um alto grau de incerteza, por exemplo:

- Pergunta 5, página 262: "Você conhece os imites de abordagens dos concorrentes?"

- Pergunta 6, păgina 262: "Você sabe se a proautividade de PSD (Pesquisa \& Desenvol. vimentol está aumentando ou diminuindo?"

Logicamente, hâ perguntas que podem ser quantificadas: 